\title{
Financieel en economisch management
}

\author{
Een proeve van beschrijving, advisering en onderzoek
}

Prof. Dr. P.J.J.M. van Loon

\section{Verantwoording 1}

Dit artikel gaat over de organisatie en sturing van de financiële en economische functie ${ }^{2}$, een onderwerp dat mij tijdens mijn loopbaan als organisatie-adviseur ongemeen heeft geboeid en waarvoor in de loop van een alantal adviesopdrachten een denkmodel is ontwikkeld dat zijn walarde in de (c.q. mijn) adviespraktijk heeft bewezen. Het is een samenvatting en verdere uitbouw van elders gepubliceerde denkbeelden en adviezen over dit onderwerp en eindigt met een indicatie van de richtingen walarin wetenschappelijk onderzoek van belang zou kunnen zijn.

Het is opvallend hoe weinig vernieuwende onderzoeksresultaten over dit onderwerp in de vakbladen en wetenschappelijke tijdschriften te vinden zijn (ik kom diar in paragraal 5 nog op terug). We kunnen speculeren over de redenen: de geringe eer die er voor (financierings- of accounting-)specialisten met dit interdisciplinaire onderwerp te behalen valt, de (voor wetenschappers) moeizaam toegankelijke praktijkkennis en ervaring, de alwezigheid van een onderzoekstraditie met haar min of meer vastomlijnde kaders die startende onderzoekers enig houvast kunnen bieden.

Mijn indruk is dat het zeker niet ligt alan een gebrek aan belangstelling vanuit de praktijk: er is een bloeiende adviesmarkı op dit terrein en vele (financiële) directeuren die ik als organisatieadviseur mocht ontmoeten. deelden mijn inzicht

Prof. Dr. P.J.J.M. van Loon is bijzonder hoogleraar Financieel Management aan de Economische Faculteit te Groningen en vice-voorzitter van de Medische Faculteit te Nijmegen. Tot 1 september 1994 was hij organisatie-adviseur bij Coopers \& Lybrand te Utrecht dat voor een goed management van de financiële aspecten van de bedrijfsvoering meer nodig was dan men op universiteit en HEAO aan vakinhoudelijke kennis meekrijgt. Er is dus, vanuit de praktijk bekeken, alle reden voor om wetenschappelijk onderzoek over financieel en economisch management te stimuleren door dit onderwerp onder de aandacht van wetenschappers te brengen.

Het exposé start in de volgende paragraaf met een beschrijving van het Vijf Taken-Model als instrument om financiële en economische activiteiten in haar onderlinge satmenhang te beschrijven. De wijze walrop deze activiteiten binnen een organisatie tot ontwikkeling (kunnen) komen, vormt het onderwerp van paragraaf 3. De voor die ontwikkeling bepalende factoren worden daarbij ingedeeld in drie verschillende groepen. In paragraaf 4 wordt een aantal onderwerpen van het financiële en economische management aangegeven waarbij de genoemde instrumenten (Vijf TakenModel en Drie Dimensionaal Ontwikkelingsmodel) zijn toegepast zodat de praktisch georiënteerde lezers zich een beeld kunnen vormen van het nut van deze instrumenten voor het structureren en eventueel oplossen van problemen op het terrein van financieel en economisch management in hun eigen organisatie. In de laatste paragraaf wordt nader ingegaan op de mogelijkheden om het instrumentarium op wetenschappelijke wijze te toetsen en waar mogelijk verder uit te bouwen.

\section{De vijf taken van de financiële en economische functie}

\subsection{Doel en relatie tot het management}

Onder het financiële en economische management verstaan we het organiseren, sturen en 
beheersen van de financiële en economische functie binnen een bedrijf. Voor het organiseren wordt in deze paragraaf een hulpmiddel gegeven in de vorm van een gestructureerde opsomming van feitelijke activiteiten die geacht worden onder deze functie, verder met F\&E-functie aan te duiden, te vallen.

Uitgangspunt daarbij is dat de F\&E-functie eenzelfde managementadvies-rol heeft als, bijvoorbeeld, de personeelsfunctie, de automatiseringsfunctie en de facilitaire functie. En evenals bij deze functies is het aan het management te beslissen in hoeverre het zelf de betreffende activiteiten uitvoert of dit aan financiële en economische experts overlaat.

\subsection{De twee Primaire Taken}

De ondersteuning die de F\&E-functie geeft aan het management kan onderverdeeld worden in twee taken, die we, ter onderscheiding van later te bespreken daaraan ondersteunende taken, de Primaire Taken van de F\&E-functie noemen (Van Loon, 1994a):

I het geven van een economische beoordeling van voorgenomen respectievelijk gerealiseerde managementbeslissingen;

2 het (adviseren over het) aantrekken (/wegzetten) van geld van (/in) de financiële markt (financiering).

Naar deze twee Primaire Taken verwijst (in omgekeerde volgorde) de naam die wij gebruiken voor de functie waaronder alle (ook de nog te behandelen facilitaire) Taken vallen: de Financiële en Economische Functie.

De activiteiten die onder de eerstgenoemde taak (economische beoordeling) vallen, hebben als gemeenschappelijk kenmerk dat ze de relevante kasstromen uit verleden, heden en toekomst bepalen en overzichtelijk weergeven ten behoeve van besluitvorming en/of rapportage door het management. Het gaat om het bepalen van de inhoud van de relevante $F \& E$-managementinformatie en de analyse ervan: wat is de (netto) omvang van de economische waarde die door het betreffende besluit wordt gegenereerd resp. welk economisch waarde-accres heeft het management met/voor de organisatie weten te creëren.
Enkele voorbeelden:

- de opbrengsten en kosten en de daaruit resulterende winst vaststellen ten behoeve van de bepaling (door het management) van de hoogte van het dividend;

- de netto contante waarde bepalen van de kasstromen ten behoeve van het besluit om een investeringsproject al dan niet te realiseren;

- de hoogte vaststellen van de (beïnvloedbare) gerealiseerde kosten ten behoeve van de verantwoording door een budgethouder/ manager.

De bedoelde activiteiten dragen in de praktijk namen zoals: (de F\&E aspecten van) planning, budgettering, control, bedrijfseconomische doorlichting, externe berichtgeving etc.

De activiteiten die onder de tweede genoemde taak, Financiering, vallen, concentreren zich op advisering over en het beheer van de geldstromen die de organisatie uit hoofde van haar primaire proces creëert. Het gaat daarbij om het aantrekken en uitzetten van gelden waarbij een afweging gemaakt moet worden tussen te betalen kosten (respectievelijk te ontvangen vergoedingen) en het te lopen financiële risico.

Waar de taak van de economische beoordeling een beslissingsondersteunend karakter heeft, kent de financiering ook transactie-gerichte activiteiten. Enkele voorbeelden:

- het (dagelijks) afromen van de creditsaldi en aanvullen van de debetsaldi op de diverse rekeningen en het resterende overschot (c.q. tekort) uitzetten (c.q. financieren);

- het opstellen van liquiditeitsplanningen en op basis daarvan adviseren over de gewenste samenstelling van het aan te trekken vermogen (rentetypen, vervaldata, hoeveelheden, contractpartners etc.);

- het realiseren van een commercial paper programm.

De activiteiten dragen in de praktijk namen als: geldstromen-, kas- en valutabeheer, operaties op financiële markten, financiële planning, werkkapitaalbeheer, vermogensstructuur etc. ${ }^{3}$

In figuur 1 zijn de relaties tussen de twee beschreven primaire taken van de F\&E-functie en de betrokken partijen binnen en buiten de organisatie weergegeven.

Voor een goede uitvoering van financieringsactiviteiten is kennis van de financiële markten 
onontbeerlijk. Daarnaast is. bij een verdere uitbouw valn deze activiteiten. kennis van de eigen organisatie van toenemend belang, bijvoorbeeld om de liquiditeitsplanning te verbeteren en een adequate adviseur te kunnen zijn voor het management inzake het hanteren van diverse financiële instrumenten.

Basis voor de economische beoordeling is daarentegen een goede kennis van de eigen bedrijfsprocessen, zowel voor de interne advisering als voor de externe verantwoording. Pas bij een verdere ontwikkeling richting strategische planning (zie ook paragraaf 3 ) is gerichtheid op externe ontwikkelingen noodzakelijk.

Figuur 1: Bij de primaire F\&E-taken betrokken partijen

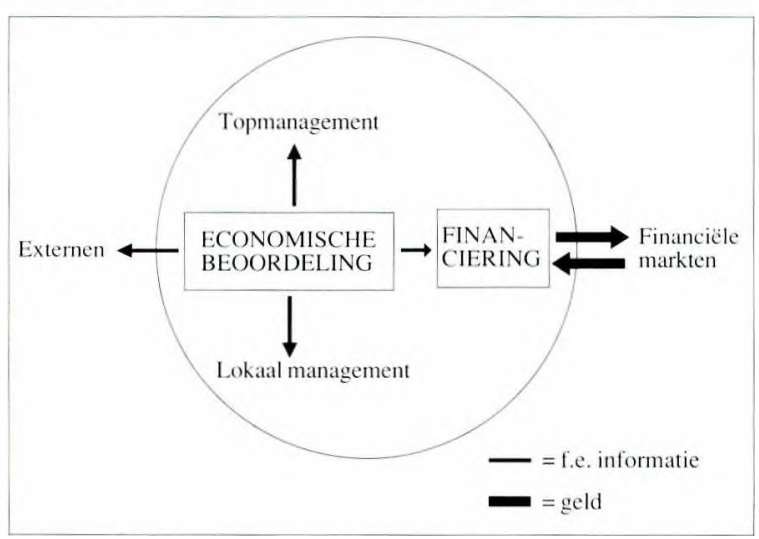

In de praktijk blijkt het niet altijd mogelijk om alle activiteiten van de F\&E-functie zonder meer in één van de genoemde twee primaire taken onder te brengen. Zo is er bijvoorbeeld discussie mogelijk over het feit of de activiteiten rond het beheren van de verzekeringsportefeuille (en het bepalen van de inhoud ervan) onder economische beoordeling dan wel onder financiering vallen. Een verdere opdeling van de betreffende activiteiten biedt dan doorgaans uitkomst. Zo kan men zich voorstellen dat het bepalen van hel verzekeringsbeleid onder de economische beoordeling valt. het afsluiten van contracten financierings-(en juridische)aspecten heeft en het athandelen van de schadegevallen ook aspecten heelt die niet onder de F\&E-functic vallen.

\subsection{De drie Facilitaire Take'n}

Om genoemde primaire taken te kunnen vervullen is (financiële en economische) informatie nodig. De produktie daarvan wordt ook tot de F\&E-functie gerekend. Binnen dit produktieproces kunnen we weer een drietal. zogenaamd facilitaire taken onderscheiden:

3 de financiële en economische informatieproduktie zelf;

4 de werkioorbereiding warbij de vraag naar F\&E-informatie wordt vertald in "werkopdrachten" voor de activiteiten op het gebied van de F\&E-informatieproduktie;

5 het administratief kwaliteitsmanagement. activiteiten die zich bezighouden met de kwaliteit van de aansturing en realisatie van de F\&E-informatieproduktie.

De activiteiten die tot talak nr. 3, de $F \& E$ informaticproduktie, behoren, houden zich bezig met het verzamelen van data, het opslaan en het daaruit destilleren van managementinformatie. Alhankelijk van het type organisatie en de wijze waarop daarbinnen activiteiten bij afdelingen zijn ondergebracht, kan een belangrijk deel van de activiteiten op het gebied van de $F \& E$-informaticproduktie daadwerkelijk buiten de administratic(s) plaatsvinden. als zijnde de afdelingen waar we toch het eerst aan denken bij dit soort activiteiten. Zo kan (een gedeelte van) de basisadministratie op de werkvloer zelf geschieden. bijvoorbeeld ten behoeve van een koppeling tussen de verantwoordelijkheid voor kwalitatief goede input en het profijt van goede (operationele) managementinformatie op zo laag mogelijk niveau in de organisatie.

Men dient hierop beducht te zijn, wanneer men de F\&E-activiteiten binnen de organisatie gaat inventariseren: zoek ook buiten de als F\&E-/ administratief aangeduide afdelingen!

De facilitaire taak werkroorbereiding heeft in de filosofie van het Vijf Taken Model twee met elkaar samenhangende aspecten. Enerzijds vallen er activiteiten onder die in de automatisering met informatic-analyse \& -planning worden aangeduid. Anderzijds bevat het de activiteiten die het werk van de $F \& E$-informaticproduktic plannen, respectievelijk de processen daarin vastleggen, verbeteren en aanpassen aan een eventueel veranderende vraag naar F\&E-informatie. In de laatstgenoemde groep activiteiten herkent men wat doorgaans onder administratieve organisatie wordt begrepen. Het zal echter duidelijk zijn dat werkroorbereiding in het Vijf Taken Model méér is 
dan alleen het beschrijven en verbeteren van administratieve procedures: het is het inrichten en aanpassen van het administratieve proces aan de steeds veranderende vraag naar financiële en economische informatie. ${ }^{4}$

Als vijfde taak is het administraticf kwaliteitsmanagement genoemd. Daaronder vallen activiteiten die zich bezighouden met het bewaken en bevorderen van de kwaliteit van het administratieve proces (dat wil zeggen: werkvoorbereiding plus $F \& E$-informatieproduktie). Basis voor deze facilitaire taak is het meten van de feitelijke gang van zaken en het opsporen van verschillen tussen planning en realisatie. Andere aspecten zijn het nagaan of de geleverde informatie ook de door de afnemers gewenste is ( $k$ waliteit is immers de mate waarin aan de behoefte van de klant tegemoet gekomen wordt) en of de werkvoorbereiding een adequate balans weet te handhaven tussen de chaos van de steeds veranderende (inteme) vraag naar managementinformatie en de starheid van (respectievelijk de moeilijk aan te passen) produktiestructuur. Deze taak houdt dus meer in dan wat doorgaans onder interne controle in een organisatie wordt aangetroffen. Vandaar dat in het Vijf Taken Model een meer aangepaste terminologie wordt gebruikt: administratief kwaliteitsmanagement.

In figuur 2 zijn de twee Primaire Taken en de drie Facilitaire Taken van de F\&E-functie in hun onderlinge relatie weergegeven.

De bedoeling van de in figuur 2 weergegeven Taken is een structuur aan te bieden waarin de activiteiten op F\&E-gebied binnen een onderneming kunnen worden ingedeeld naar min of meer homogene categorieën.

Figun 2: De onderlinge samenhang massen de vijf Taken

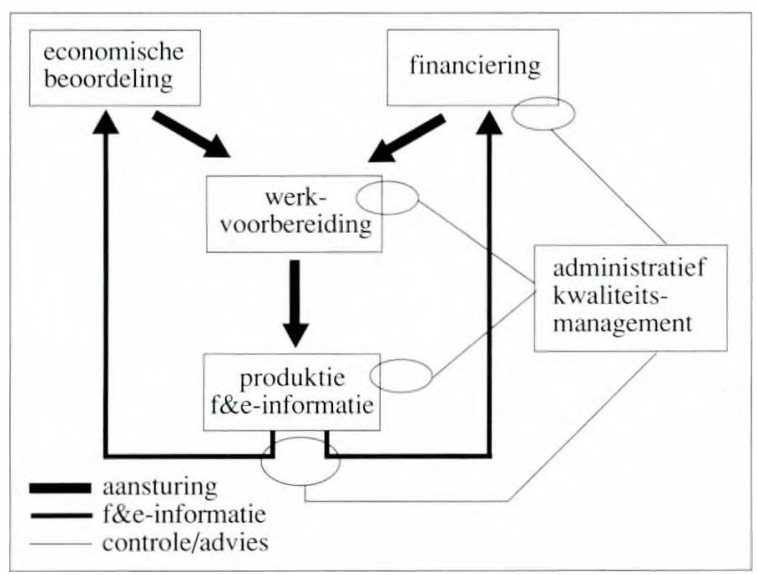

Het management van de $F \& E$-functie is niet als een aparte taak benoemd omdat dit meer de coördinatie van de activiteiten behelst dan als een eigenstandige, vakinhoudelijk nieuwe activiteit kan worden beschouwd. Soms wordt deze activiteit gecombineerd met de verantwoordelijkheid over een van de vijf Taken (bijvoorbeeld het Hoofd FEZ tevens concerncontroller). Soms is het een full time functie binnen de F\&E-afdeling (hoofd FEZ met daaronder een aparte controller. treasurer, comptabele e.d.). Het is echter ook mogelijk dat het management zelf deze functie op zich neemt.

\section{Ontwikkeling van de financiële en economische functie}

\subsection{De drie ontwikkelingshepalende factoren}

De in de vorige paragraaf beschreven Taken en daarbinnen te onderscheiden activiteiten komen niet in gelijke mate bij iedere onderneming of non profit-organisatie voor. Dit heeft te maken met het ondersteunende karakter van de F\&E-functie: zij ondersteunt het management bij zijn besluitvorming inzake financiële en economische aspecten. De mate waarin het management dit soort ondersteuning wenst, is dus in belangrijke mate bepalend voor de inrichting van de F\&E-functie. Een tweede belangrijke factor is het instrumentarium dat de F\&E-functie ter beschikking staat: aanwezige informatiesystemen, beschikbare financiële instrumenten op geld- en kapitaalmarkten, planning \& control-procedures, -documenten etc.

We onderscheiden derhalve drie elkaar beïnvloedende factoren die de ontwikkeling van de financiële en economische besturing in de onderneming bepalen:

I Het planmatig denken waarmee het management inkomsten en uitgaven resp. opbrengsten en kosten in de besluitvorming meeneemt. bijvoorbeeld blijkend uit de inrichting van het planning- en controlproces;

2 De professionaliteit van de F\&E-functionarissen, blijkend uit de aanwezige taken, de omvang van de formatie en de kwaliteiten van de F\&E-functionarissen;

3 Het instrumentarium dat de F\&E-functionarissen ter beschikking staat.

Een goed functionerende F\&E-besturing kent een harmonieuze afstemming van het ontwikke- 
lingsniveau in de drie factoren. Een voorbeeld van discrepantie is een onderneming met een ad hoc beslissende directie (planmatig denken) waarvan de controller probeert een jaarplanning en budgettering op te zetten (professionaliteit) en die daarin gefrustreerd wordt door de steeds van koers wijzigende directie en door een financieel systeem waarmee geen adequate tussentijdse realisatierapporten kunnen worden gegenereerd (instrumentarium).

Ieder van de drie factoren kent haar eigen ontwikkelingsgang(en). Om een analyse te kunnen geven van de situatie van de financiële en economische besturing binnen een specifieke onderneming (in termen van: zijn de ontwikkelingsniveaus van de drie factoren wel/niet goed op elkaar afgestemd?) zal men een beeld van ieder van deze ontwikkelingsgangen moeten hebben alvorens ze met elkaar te kunnen vergelijken.

\subsection{Planmatig denken ran het management}

De ontwikkeling van het financiële en economische denken en handelen van het management wordt gekenmerkt door de planmatigheid waarmee het de financiering en interne middelenverdeling ter hand neemt. Auteurs hebben in dit proces een van vier (Gluck c.s., 1982) tot acht (Izeboud, 1993) variërend aantal stadia onderscheiden. In mijn advies- en onderzoekswerk (Van Loon, 1993) hanteer ik het klassieke vijf fasen model, waarvan mijn vroegste vindplaats een publikatie van Branch uit 1962 is, geciteerd in het inleidende marketing handboek van Kotler (Kotler, 1983, pp. 512 - 514). Branch beschrijft een vijftal stadia van ontwikkeling waarin zich het formele planning-en control proces van een organisatie kan bevinden.

Ik zal op basis daarvan de achterliggende ontwikkeling in het financiële denken en handelen van het management nader aanduiden, daarbij de bewoordingen van Kotler parafraserend.

Het eerste stadium is de unplanned stage (door mij in "non planning" vertaald), waarin het management al zijn tijd nodig heeft om fondsen te verwerven, huisvesting en inrichting te regelen, personeel aan te trekken en in te werken en klanten te werven. Het management opereert van dag tot dag en heeft geen tijd (of zin) om expliciet financiële beleidslijnen voor langere termijn binnen de organisatie uit te zetten.
Dit blijkt onder andere uit het feit dat de financiële besturing geschiedt op basis van historische gegevens zoals (te laat verschijnende) jaarrekeningen en/of tussentijdse financiële rapportages over afgelopen periodes.

In de daaropvolgende budgeting system stage (financiële budgettering) maakt het management voor zichzelf een expliciet een beeld, in financiële termen, van de komende periode om meer anticiperend met de beschikbare middelen om te kunnen gaan.

Het gevolg is dat er een begrotingsproces wordt ingericht om meer grip op de kasstroom te krijgen. Er wordt een schatting gemaakt van de te verwachten inkomsten en uitgaven en daaruit resulterende kasstroom. Bij grotere ondernemingen komen er budgethouders die eigen begrotingen opstellen of toegewezen krijgen. Deze begrotingen luiden in financiële termen en zijn nog niet expliciet gebaseerd op plannen inzake de sluring van het primaire proces.

In het volgende stadium, de anmual-planning stage (planmatige budgettering) verandert de plaats van financiële en economische aspecten in het toekomstdenken van het management: zij worden als gevolgen gezien van voorgenomen activiteiten op het gebied van verkoop, produktie, research en dergelijke, waarmee bij de besluitvorming (in termen van: te ondernemen activiteiten en niet meer in termen van: financiële kaders) expliciet rekening gehouden gaat worden.

Er komt daarom een inhoudelijk en financieel samenhangende planningprocedure resulterend in een jaarplan. Daarin worden de organisatiedoelstellingen voor het komend jaar vastgesteld en vertaald naar deelplannen per budgethouder die daar dan tevens de benodigde middelen voor krijgt. Bedrijfseconomen in Nederland spreken dan van een budget: zijnde een taakstellende begroting waarin een koppeling is gelegd tussen de taken van de budgethouder en de daarmee te behalen inkomsten, resp. de daarvoor ter beschikking gestelde middelen.

De long-range-planning stage (meerjarenplanning) wordt bereikt zodra het management in zijn financiële denken onderscheid gaat maken tussen besluitvorming gericht op de gewenste 
vorm van de onderneming en haar activiteiten op langere termijn (met onder andere de daaruit voortvloeiende investeringen en vermogensstructuur) en de benutting van de aanwezige capaciteit van de onderneming op korte termijn (met de daaruit voortv loeiende operationele budgetten en korte termijn financiering).

Dan wordt binnen de budgetteringsprocedure het onderscheid geïntroduceerd tussen de langeen de korte termijnplanning. Er wordt als het ware een overlegronde vóór de jaarplanning geschoven waarin vanuit een lange termijn perspectief de kaders voor de budgettering worden bepaald (bijvoorbeeld inzake marketingplan, investeringen, formatie-opbouw, lange-termijnfinanciering en dergelijke).

In de strategic-planning stage (strategische planning) oriënteert het management zich primair op wat in de (markt)omgeving van de onderneming staat te gebeuren. Vanuit dat perspectief kijkt het naar de gewenste feitelijke vormgeving van de onderneming en haar activiteiten op (middel) lange termijn en de benutting van de aanwezige capaciteit op korte termijn.

Datrom zal het management het planningproces zodanig inrichten en managen dat de organisatie adequaat inspeelt op de mogelijkheden die zich in een steeds veranderende omgeving voordoen in termen van af te stoten en nieuw te entameren activiteiten, rekening houdend met de daaruit voortvloeiende financiële en economische consequenties.

De bovengenoemde vijf stadia geven een systematische beschrijving van de wijze waarop de financiële en economische aspecten een veranderende rol spelen in de evoluerende besluitvorming van het management.

Met het stijgen van het niveau van planmatig denken worden hogere eisen gesteld aan de F\&Eondersteuning en het gehanteerde instrumentarium. Dit zijn de twee andere factoren waarvan we de ontwikkelingsgang zullen schetsen.

\subsection{F\&E-taken en deskundigheid}

In paragraaf 2 beschreven we de vijf Taken die binnen de F\&E-functie kunnen worden onder- scheiden. Deze Taken komen niet alle vijf tegelijkertijd tot ontwikkeling. Er kunnen twee ontwikkelingstrajecten worden onderscheiden zoals weergegeven in figuur 3 .

Figaner 3: Ontuikkelingsgangen binnen de factor professionaliteit

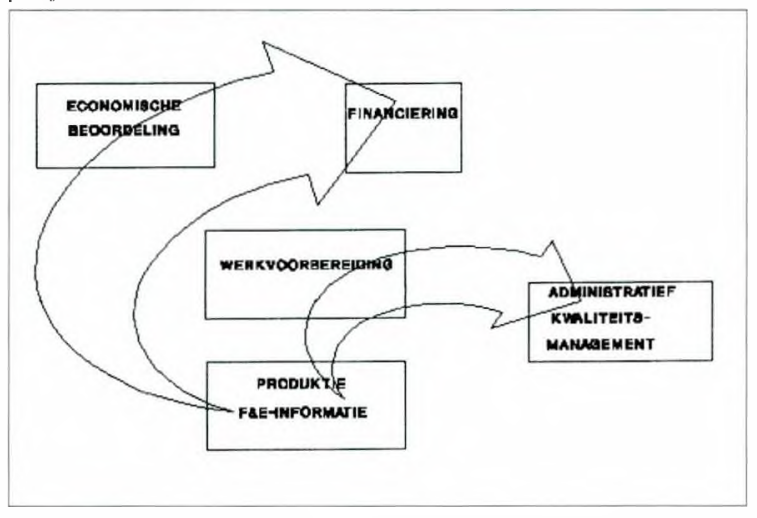

De linker pijl in figuur 3 vertegenwoordigt de ontwikkeling van de F\&E-functie naar de twee Primaire Taken. Aanvankelijk is de aandacht van de F\&E-functionarissen vooral gericht op de externe berichtgeving en de uit dien hoofde te stellen eisen aan de financiële administratie ( $F \& E$-informatieproduktie). Later neemt de aandacht voor management accounting toe uit hoofde van de groeiende vraag van het management naar $F \& E$-informatie door professionals (resp. een toenemende delegatie van de analyse daarvan naar de F\&E-functie economische heoordeling). Bij verdere ontwikkeling van de F\&E-functie zien we vervolgens een verdere professionalisering van de financiering, veroorzaakt door de groeiende omvang van de kasstromen en door het feit dat de economische beoordeling haar aandacht gaat uitbreiden van de primaire processen naar de ondersteunende processen. zoals de treasury.

De rechter pijl van figuur 3 geeft de volgtijdelijke opkomsı van activiteiten binnen het administratieve proces weer. Aanvankelijk vooral gericht op de uitbreiding en verbetering van de $F \& E$ informaticproduktie. In een volgend stadium, wanneer dit produktieproces grootschaliger en ingewikkelder wordt (bijvoorbeeld vanwege het toenemend aantal deeladministraties en/of autonome decentrale administratieve units), krijgen de activiteiten betreffende de inrichting en planning van dit proces een groeiende aandacht (werkiroorbereiding). Deze activiteiten worden verder gestimuleerd door de opkomst van managers als 
interne gebruikers van F\&E-(management)informalie met diverse en steeds wisselende wensen. Hoewel er doorgalans vanaf het begin (operationele) controles in het administratieve proces zijn aangebracht. is een doorbraak van operationele controle naar administratief kwaliteitsmanagement eerst goed mogelijk als naast de produktiegerichte activiteiten ook de activiteiten inzake de werk voorbereiding een zeker niveau van ontwikkeling hebben bereikt.

Binnen beide ontwikkelingstrajecten kunnen we per Taak deeltrajecten onderscheiden. die we hier schetsmatig weer zullen geven:

- produktic ran $F \& E$-informatie: van financiële informatie ten behoeve van de externe (financiële) berichtgeving, via zuiver financiële informatie voor het eigen management naar een koppeling aan niet-financiële managementinformatie;

- economische beoordeling: van puur financiële beoordeling, naar koppeling van taken/activiteiten aan (linanciële en) economische aspecten en dat weer van een eenjarig, via een meerjarig naar een strategisch perspectief:

- financiering: van ad hoc saldibeheer via cash management op basis van liquiditeitsplanning naar corporate finance vanuit een meerjarig en later vanuit een strategisch perspectief:

- nerkoorbereiding: van vastlegging van bestaande procedures. via efficiencyverbetering naar vanuit informatiebehoefte aangestuurde inrichting van de administratie;

- Kwaliteitsmanagement: van fraudebestrijding en rapportages over naleving procedures via advisering over de richt lijnen voor de werkvoorbereiding naar advisering inzake werkvoorbereiding en fraudepreventie gestuurd vanuil de (door de klant gewenste) kwaliteit van de informatie.

Per Taak worden doorgaans niet alle deeltriajecten doorlopen vóórdat een volgende Taak tot ontwikkeling komt: er is als het ware sprake van een dakpansgewijze ontwikkeling binnen ieder van beide ontwikkelingstrajecten.

\subsection{Het instrumentarium}

Tijdens het ontwikkelingsproces zal het instrumentarium dat de managers en de F\&E- functionarissen ter beschikking statat voortdurend moeten worden aangepast (zie figuur 4). Voor de economische beoordeling betreft het voornamelijk de kwaliteit van de F\&E-informatie (inhoud. wijze van produktie en dergelijke) en de inrichting van de planning-en controlprocedure. Voor de financiering betreft dit zowel de kwaliteit van de relevante $F \& E$-informatie als de beschikbare financieringsinstrumenten.

Figun 4: Ee'n ontwikkelingsgang van de

factor instrumentariam

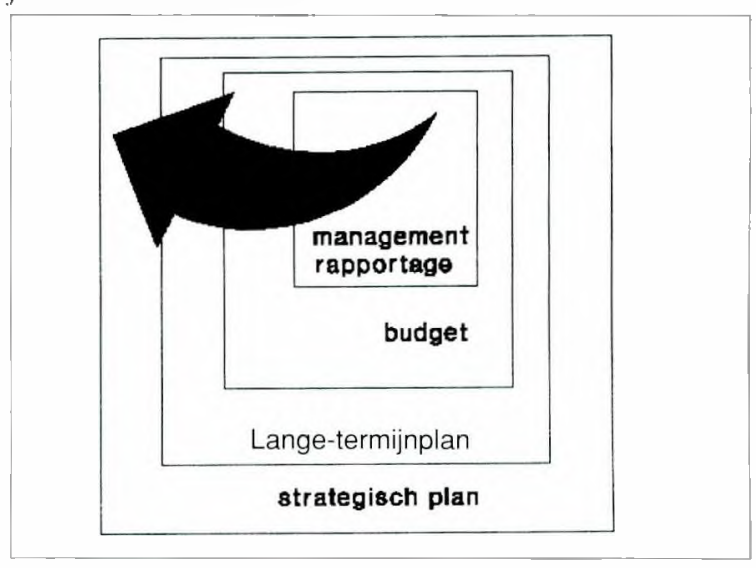

Gegeven de beschikbare ruimte beperken we ons bij wijze van voorbeeld van ontwikkeling van F\&E-instrumentarium tot management informatie in de vorm van het samenstel van planning \& control-documenten zoals ik dat eertijds samen met collega Izeboud heb beschreven (Izeboud en Van Loon, 1991) en dat een organisatie in de loop valn haar planmatige ontwikkeling kan galan maken.

Voor een strategisch aangestuurde organisatie zijn de planning \& control-documenten pas echt adequaat als er ian drie eisen wordı voldaan:

1 consistentic: de opeenvolgende documenten, gaande van strategisch plan naar (periodieke) managementrapportage, vormen steeds een eenduidig kader voor het volgende document:

2 flexibiliteit: het opstellen van een document lager in de hiërarchie (dat is: het nader uitwerken van een hoger document) kan leiden tot een (tussentijdse) herziening van de inhoud van het hogere document (ook wel "beleidsmatige terugkoppeling" genoemd);

3 reagerend vermogen: informatie in de tussentijdse managementrapportages heeft een zodanige inhoud dat deze als basis kan dienen voor het bijstellen van (alle) hogere plannings- 
documenten (ook wel "operationele terugkoppeling" genoemd).

Het vergt een langdurig proces van vallen en opstaan om uiteindelijk tot zo'n consistente set van naar elkaar verwijzende plannen te komen en daarbij het besluitvormingsproces ten behoeve van de (jaarlijkse) invulling en tussentijdse bijstellingen ervan optimaal in te richten.

In veel bedrijven zien we dan ook strategische beleidsdocumenten en lange-termijnplannen bestaan die te hooi en te gras worden gebruikt bij budgettering en tussentijdse evaluatie van de stand van zaken. De aanwezigheid van deze documenten wijst dan weliswaar op een (in zekere mate) strategisch georiënteerd management maar ook op een voor dat niveau van (de factor) planmatig denken achterblijvend planning \& control-instrumentarium.

\section{Toepassingsmogelijkheden van beide modellen}

De ervaring die tot nu toe is opgedaan met het Vijf Taken Model en het Drie Factoren Ontwikkelingsmodel strekt zich uit over zes gebieden die in deze paragraaf in het kort zullen worden beschreven.

\section{$4.1 F \&$ E-activiteiten in kaart brengen}

Een eerste toepassingsmogelijkheid van het Vijf Taken Model is het structureren van de inventarisatie van activiteiten binnen een organisatie naar de vijf taakgebieden. In principe zullen in een volgroeide $F \& E$-functie onder ieder van de vijf Taken activiteiten te vinden zijn. Deze inventarisatie is onontbeerlijk voor een gedegen gedachtenvorming inzake de gewenste organisatie van de F\&E-functie.

Een drietal adviezen voor de uitvoering van de inventarisatie:

a Inventariseer de activiteiten niet alleen per zelfstandig organisatie-onderdeel, maar doe dit ook voor de organisatie als totaal om erachter te komen welke taken goed vertegenwoordigd zijn en welke expertise er überhaupt niet aanwezig is in de organisatie.

b Zoals in paragraaf 2.3 reeds vermeld, dient het onderzoek zich niet te beperken tot de F\&Ec.q. administratieve afdelingen en/of F\&E- functionarissen, omdat activiteiten die volgens de eerder gegeven beschrijving onder de F\&Efunctie vallen ook door "non-financials" kunnen worden verricht (bijvoorbeeld de baliefunctionaris die gegevens over klanten (potentiële debiteuren) in het systeem inbrengt).

c Ontkoppel zoveel mogelijk de inventarisatie van wat er feitelijk gebeurt van de bestaande organisatie- en verantwoordelijkheidsstructuur, tradities, informele afspraken, personen en dergelijke.

Dit laatste is ook de reden waarom aan vier van de vijf Taken (financiering is de uitzondering) namen gegeven zijn die verschillen van in de praktijk gangbare aanduidingen van personen/afdelingen die men er intuïtief mee zou associëren:

- economische beoordeling en niet "control", "planning \& budgettering" of "accounting", omdat op dit soort afdelingen doorgaans ook activiteiten plaatsvinden die onder de $F \& E$ informatieproduktie vallen;

- werkvoorbereiding en niet "administratieve organisatie" omdat bij de laatste term in de praktijk vaak alleen gedacht wordt aan de inrichting van de administratie uit het oogpunt van efficiency en controleerbaarheid ten behoeve van de externe berichtgeving (financial accounting) en veel minder aan de "orderintake"-functie van dit taakgebied: welke (steeds veranderende) informatie wil het management (management accounting) en hoe kan de organisatie van de administratie daar zo goed mogelijk op worden ingericht;

- F\&E-informatieproduktie en niet "(financiële) administratie" omdat het (gestructureerd) verzamelen van data en het bewerken tot informatie ook buiten de administratie plaatsvindt: bijvoorbeeld: data kunnen op de werkvloer verzameld worden en het (gestructureerd) bewerken tot informatie kan geschieden in planning \& control-afdelingen of door managers zelf;

- Administratief kwaliteitsmanagement en niet "interne controle" of "interne accountant", enerzijds om aan te geven dat de functie bij opkomst van management accounting een verschuiving in benadering dient te ondergaan (van kwaliteit afgeleid uit externe eisen te stellen aan rapportages naar: kwaliteit afgeleid uit (veranderende) wensen van de interne gebruikers c.q. het management), anderzijds 
om aan te geven dat men zich bij succesvolle afdelingen op dit terrein niet beperkt tor hel signaleren en rapporteren van fouten c.y. onvoldoende kwaliteit (controle in enge zin). maar dat men zich ook verantwoordelijk voelt voor een goede advisering van zowel eindverantwoordelijken als lunctionarissen op de (administratieve) werkvloer om de administraltieve kwaliteit te verbeteren en daar actiel" in participeert ("vuile handen maakt").

\section{t.2 Verhogen ran de $F \&$ E-professionaliteit}

Daartoe is het noodzakelijk de spreiding van de activiteiten per taakgebied over de betreffende afdelingen van de organisatic en daarbinnen over de daar werkende functionarissen in kaart te brengen.

Vervolgens dient het management te beslissen of al deze activiteiten gewenst zijn resp. of nieuwe activiteiten toegevoegd dienen te worden. Ook zal het aan moeten geven welke activiteiten het zelf uit wil voeren en welke het alan (meer) professionele functionarissen wil delegeren.

Een volgende stap is het herschikken van de (gewenste) activiteiten tot meer homogene clusters per functionaris en/of per afdeling, dat wil zeggen: clusters waarin een hoger percentage activiteiten (gemeten in soorten en/of bestede uren) tot één en dezelfde Taak (van het Vijl Taken Model) behoort, respectievelijk tot een en dezelfde activiteit binnen een taakgebied.

Uiteraard is dit een noodzakelijke maar nict voldoende voorwaarde om tot verhoging van de professionaliteit te komen. Datartoe is het ook noodzakelijk om bij de gevormde meer gespecialiseerde functies en afdelingen ook de juiste mensen te vinden ( respectievelijk daartoe op te leiden) en on een goede coördinatic tussen de (meer verkokerde) specialisten te realiseren.

\subsection{Selecteren geschikte $F \& E$-functionaris}

Diarmee komen we op een derde toepassingsgebied van het Vijf Taken Model: het op een meer gestructureerde manier vanuit de aard der activiteiten kunnen overleggen over de geschiktheid van kandidaten voor bepaalde functies.

Daurbij spelen niet alleen formele opleidingseisen een rol. Ook de persoonlijkheid van een functionaris makkt hem/haar meer of minder geschikı voor een bepalald type specialisme.
Zo vereist de cash management-functie een transactiegerichte handelaar die snel weet in te spelen op zich voordoende (veranderingen in) situaties: hij moet kunnen improviseren en nict bang zijn on beslissingen te nemen. Bij veel activiteiten op het terrein van $F \& E$-informaticprodukrie zijn "systematen" nodig: functionarissen die nauwkeurig weten te werken binnen een stelsel regels en richtlijnen en daarbij een hoge mate van efliciency weten te realiseren.

Het expliciteren van hel besef dat bij verschillende Taken verschillende typen mensen horen. leidt ertoe dat deze factor actief gebruikı kan worden om problemen binnen de F\&E-functie op te lossen: aan de opleiding en kemnis van een persoon is doorgalans meer te veranderen dan alan zijn/haar karakter.

\subsection{Beheersing en controle ran $F \& E$ activiteiten}

Het vierde toepassingsgebied betreft het alanbrengen van funcliescheidingen. Zoals boven reeds aangegeven, verschillen de Taken qua aard der activiteiten en is het als zodanig nuttig. voor grotere organisaties, de Taken bij aparte lunctionarissen respectievelijk afdelingen te leggen.

De indeling nalar de vijl lalakgebieden kin echter ook een hulpmiddel zijn om de werking van de F\&E-functic beter te kunnen sturen en controleren. We noemen enkele argumenten voor scheiding van verantwoordelijkheid voor de vijf Taken:

- activiteiten die zich bezighouden met het beheer valn de kalsstromen (financiering) dienen gescheiden te worden van de registratie ervan ( $F \& E$-informaticproduktie) om cen objectieve rapportage over de feitelijke gang van zaken bij het kasbeheer te waarborgen;

- verder dienen activiteiten inzake economische beordeling gescheiden te worden van de $F \& E$-informatieproduktie die daarvoor nodig is, enerzijds vanwege het feit dat een combinatie van meer analytisch/reflexieve activiteiten (economische beoordeling) en operationele activiteiten ( $F \& E$-informaticproduktie) bij tijdgebrek zal leiden tot prioritering van laatstgenoemde (eersi de brandjes blussen). anderzijds vanwege het feit dat de informatievragen van de economische beoordeling niet op voorhand beïnvloed of beperkt moeten worden door de actuele mogelijkheden van het linanciële informatiesysteem: 
- verantwoordelijkheid voor de werkvoorbereiding en voor de $F \& E$-informatieproduktic dienen gescheiden te worden, on de voorhereiding los te koppelen van de druk op de dagelijkse gang van zaken binnen de produktie en van de neiging op de werkvloer om zo weinig mogelijk le veranderen (uit een oogpunt van efficiency). en om de intermediaire rol lussen informatievragers en informatieproducenten met name naar ecrstgenoemden toe walar te kunnen maken;

- om een onathankelijke beoordelings- en adviesrol te kunnen vervullen zal de verantwoordelijkheid voor het administratieve kwaliteitsmanagement gescheiden moeten worden vin de verant woordelijkheid voor (gedeclten van) het administratieve proces (werkinorbereiding $+F \& E$-informaticproduktio).

Vanuit een externe berichtgevings-optiek word deze verantwoordelijkheid zelis buiten de afdeling FEZ gelegd, bijvoorbeeld direct rapporterend alan de (hoofd)directie. Indien men echter de ontwikkeling van de management accounting adequalat wil ondersteunen. en dus het accent van controle nalar advisering van de werkvloer wil verleggen. dient de verantwoordelijkheid voor deze specifieke activiteiten van het administratief kwaliteitsmanagement binnen de F\&E-afdeling zelf geplatitst le worden!

\subsection{Bepalen van activiteiten die getde centraliseerd dienen to worden}

Het vijfde gebied waar men van het Vijf Taken Model gebruik kall maken is de besluitvorming over centraliseren of decentraliseren van managementverant woordelijkheden en over de daarbij passende inrichting en organisatic van de F\&Efunctic.

Nadat de bestaande activiteiten zijn geïnventariseerd en de discussie over het uibreiden of inkrimpen van dit scala aan activiteiten voor de organisatie als geheel is gevoerd. resteren in een organisatie met meerdere management-echelons de volgende vragen:

a welke Taken en/of onderliggende activiteiten gaat het management op de verschillende echelons zelf doen (komen er bijvoorbeeld F\&E- directeuren dan wel general listische portefeuillehouders met onder meer Financiën in hun portefeuille);

b welke Taken en/of onderliggende activitciten worden op de verschillende echelons naar

F\&E-functionarissen gedelegeerd;

c welke Taken en/of onderliggende activiteiten worden van buitenaf ingehuurd of ingekocht.

Hel moge duidelijk zijn dat deze vragen voor ieder van de besproken vijl Taken anders beantwoord kumnen worden, afhankelijk van de specifieke situatie van de organisatie (besturingsmodel. beschikbare deskundigheid, traditie/cultuur en dergelijke). Zo zal de ene organisatie. in het kader van decentralisatie, besluiten economische beoordeling zoveel mogelijk decentraial te platatsen in de vorm van dienst- en affelingscontrollers matr de $F \& E$-informatieproduktic centraal binnen één administratic met één financieel systeem te organiseren, terwijl een andere organisattie juist het omgekeerde (centrale planning \& budgettering. decentrale administrat ies op eigen systemen) doet en een derde organisatie beide taken zoveel mogelijk decentraal zal willen plaatsen. Een bepalalde omvang van een centrale control en administratie blijft natuurlijk altijd nodig wil de organisatie geen balkanachtige structuur krijgen.

\subsection{Bepalen van de gevenste ontwikkelingsrichuing van de $F$ dE-functie}

Het laatste toepassingsgebied dat in het kader van dit artikel besproken wordt, is de besluitvorming over de gewenste ontwikkelingsrichting van de F\&E-functie.

Op basis van de in liguur 3 geschetste twee ontwikkelingsrichtingen valn de F\&E-functie, en gegeven de inventarisatie van aanwezige activiteiten met behulp van het Vijf Taken Model, kan een gerichte besluitvorming plaatsvinden over de meest wenselijke volgende stap voor de betrokken organisatie in het upgraden van haar ondersteuning op F\&E-terrein.

In paragraaf 3 is reeds aangegeven dall daarbij rekening gehouden moet worden met enerzijds de deskundigheid en ambitie van het management om F\&E-aspecten in zijn besluitvorming mee te nemen en anderzijds met het beschikbare F\&Einstrumentarium.

In paragraf 2 hebben we al enkele voorbeelden gegeven watarbij de te onderscheiden drie 


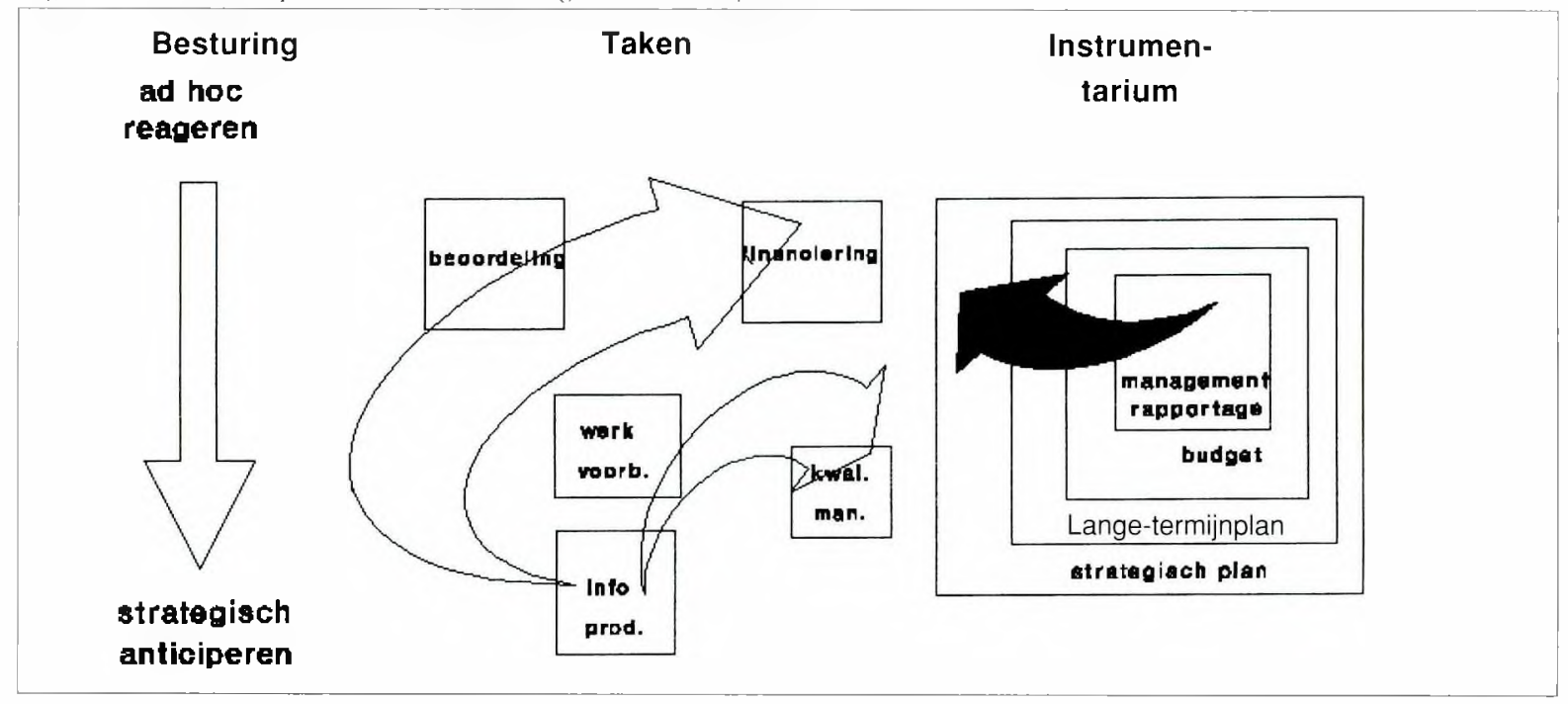

factoren in haar ontwikkeling ten opzichte van elkaar uit de pas lopen en daardoor fricties geven in de F\&E-besturing van een onderneming. Voor een harmonieuze ontwikkeling dient dit vermeden te worden: het niveau van planmatig denken van het management, de F\&E-deskundigheid en het instrumentarium dienen op elkaar afgestemd te zijn (zie figuur 5 ).

De ervaring van de schrijver met F\&E-besturingsproblemen is dat deze vaak opgelost zijn zodra een achterblijvende of vooruitlopende factor aangepast wordt aan het niveau van de andere twee. Een oplossing van he1 probleem in subparagraif 3.1 kan bijvoorbeeld best zijn: het vervangen van de controller door een administrateur omdat de aard van de business en de omvang van het bedrijf planmatige financiële sturing onmogelijk maken.

Uiteraard lijkt dit meer op een pragmatische dan optimale oplossing. Immers, omdat de F\&Efunctie ondersteunend is aan het management begint de koninklijke weg voor hel bepalen van het gewenste ontwikkelingsniveau van de drie factoren bij de inschatting welk niveau van planmatig denken van het management ideaal resp. haalbaar is. Van daar uit kan men dan bepalen wat aan de andere factoren gedaan moet worden om tot een harmonieuze combinatie te komen.

Beide wegen laten de mogelijkheid open dat de oplossing voor een onderneming met financiële beheersproblemen niet gezocht moet worden in het streven naar een hoger niveau van planmatig denken en handelen: een strategisch geplande onderneming is niet het panacee tegen alle financiële kwalen. Hoe hoger men stijgt op de planmatigheidsladder des te hoger worden de kosten van een adequate $F \& E$-functie en een adequaat instrumentarium. Deze kosten zouden, idealiter, afgewogen dienen te worden tegen de baten die zo 'n indringende aandacht voor het buitengebeuren met zich meebrengt.

\section{Perspectieven voor onderzoek}

Samen met een aantal collega's die genoemde modellen in de praktijk hebben toegepast als diagnose-instrument heb ik een tweetal observaties die pleiten voor een wetenschappelijke fundering van de analyse:

1 De indeling in stadia van planmatig denken. in de te onderscheiden Taken binnen de F\&Efunctie en in het F\&E-instrumentarium blijkt een geschikt instrument om het management inzicht te geven in de stand van de F\&Ebesturing van zijn onderneming.

2 Het levert voor het betrokken management ook een herkenbaar plaatje van de fricties en problemen die de feitelijke situatie met zich meebrengt en daarmee een goede basis voor het zoeken naar oplossingen daarvoor. Die oplossingen zijn doorgaans te beschrijven in termen van verder ontwikkelen van een of meerdere van genoemde drie factoren.

In bedrijfseconomische leerboeken wordt niet of slechts terloops op de vraagstelling van de inrichting van de F\&E-functie ingegaan. Het accent ligt daar doorgaans op (het optimaliseren 
van) de inhoud van de activiteiten (zic bijv. Brealey \& Myers. 1991. Horngren \& Foster, 1994). Een uitzondering op deze regel geldt voor het vakgebied der administratieve organisatie waarbij administratieve procedures ontworpen worden mede rekening houdend met de optimale organisatie van het administratieve proces (dic weer athankelijk is van het type bedrijf en de gekozen organisatiestructuur. zie bijv. Starreveld. 1985).

In wetenschappelijke publikaties. matar meer nog in vakpublikaties, wordt wel eens over de vraigstelling geschreven. De aanpak is dan doorgatans fragmentarisch: men beperkt zich tot een van de vijf F\&E-taken (zie bijv. Huys. 1990 over control (i.e. economische beoordeling), Van Alphen en Reeders. 1988, over treasury (i.e. financicring). Breedveld, 1991. over interne controle (onderdeel van hel administratief hwaliteitsmanagememt). Bovendien hebben de meeste publikaties met elkiar gemeen dat sprake is van een be- of voor-geschreven blauwdruk waarbij geen plaats is voor denken in termen van organisatie-ontw ikkeling: bij verschillende stadia van ontwikkeling van de organisatie passen mogelijk andere invullingen van de F\&E-funclie. Esseling vormt daarop cen uitzondering met $\angle i j n$ beschrijving van verschillende ontwikkelingsstadiat binnen de administratieve organisatic (Esseling. 1992).

Meer recente publikaties (Flens c.a.. 1992. over fimanciering. Van Loon. 1992. over cash management (onderdeel van fincunciering) en lzeboud. 1993. over economische beondeling). plaatsen de beschrijving van één F\&E-taak in het kader van de gehele F\&E-lunctie. Bij Flens is ook sprake van verschillende stadiat van ontwikkeling van de financieringstiak.

In vervolg op deze publikatlies ontwikkelde de schrijver dezes een methodiek om de activiteiten van alle vijf $F \& E$ taken te meten en naar stadia van ontwikkeling te classificeren. Deze methode is in een pilot-studie toegepast bij een vijftal bedrijven van verschillende omvang en uiteenlopende bedrijfsprocessen ( Van Loon. 1993). Deze pilotstudie heeft interessante resultaten opgeleverd voor het verbeteren van de methodiek inzake de inventarisallie van aanwezige Taken en activiteiten. Ook heeft deze pilotstudie aanwijzingen opgeleverd hoe hel feitelijk nivealu van planmatig denken van het management beter zou kunnen worden gemeten dan alleen op basis van door de F\&E-funclie verrichte activiteiten (die immers niet hoeven te sporen met het door het management zelf gewenste niveau van planmatig denken).

Hel onderzoek naar de (dynamick van de) derde ontwikkelingsfactor. het instrumontarium. staal nog in zijn kinderschoenen. Weliswaar zijn er voor alzonderlijke instrumenten inventariserende publikaties (bijvoorbeeld. ieder zichzelf respecterend valkblad voor administrateurs en controllers brengt tegenwoordig vergelijkende testen over fïnanciële pakketten en er zijn verschillende publikalties inzake financiële instrumenten. zoals Rivett e.a.. 1991) maar literatuur over de ontwikkeling van het gebruik daarvan binnen ondernemingen ontbreekt tot nu toe.

Mijn conclusie is dan ook dat er een breed. uitdagend terrein open ligt voor onderzoek inzake de organisatie van de F\&E-functie en hoe deze tijdens de ontwikkelingsgang van het bedrijf wordt (of zou moeten worden) angepast.

\section{I T E R A T U U R}

Alphen, W. van en A. Reeders, (1988), De organisatie van de treasuryfunctie in grote Nederlandse bedrijven, Tiidschrift Financieel Management, pp. $63-70$

Branch, M.C., (1962), The Corporate Planning Process, American Management Association.

Brealey, A. en S. Myers, (1991), Principles of Corporate Finance, 5e druk, McGraw Hill.

Breedveld - Krans, S., (1991), Het functioneren van interne accountantsdiensten bij ondernemingen in Nederland, De Accountant, pp. $559-563$.

Esseling, E., (1992), Het beheer van de administratieve organisatie, Tiidschrift Financieel Management, nr. 6, pp. 54 - 62

Flens, M. A. Klaassen, P. van Loon (red.), (1992), De treasury-functie, Kluwer.

Gluck, F., S. Kaufman en A. Walleck, (1982), The Four Phases of Strategic Management, Journal of Business Strategy. part 3, pp 9 - 21.

Horngren, C., G. Foster en S.M. Datar, (1994), Cost accounting, a managerial emphasis, 9e druk, Prentice Hall.

Huys, G., (1990), De functie van de controller, in: W. Missorten, J. Schoonderbeek, J, van de Velde en H. Wijnberg (red), Praktiikboek Management, Kluwer.

Izeboud, C., (1993), (Management)accounting en Control(ler), inaugurele rede, Vrije Universiteit Amsterdam. Izeboud, C. en P. van Loon, (1991), Het financiële besturingssysteem, in: Van der Wolk (red.), Financieel Handboek voor het Bedriff, De Toorts \& Van der Wolk.

Kotler, P., (1983), Principles of Marketing, 2e druk, PrenticeHall.

Loon, P. van en R. Reinders Folmer, (1992), Cash Management, taken, instrumenten, organisatie en informatiebehoefte, in: Handboek Management in overheidsorganisaties, Samsom, pp. F3190-1 - F3190-29.

Loon, P. van, (1993), De ontwikkeling van het financieeleconomische management in organisaties, op weg naar de meetbaarheid ervan, inaugurele rede, Samsom.

Loon, P. van, (1994), Dynamiek in de financieel-economische 
functie, in: Helden, J. van, J. van Kollenburg, P. van Loon (red.), Financiële aspecten van non-profit management, Samsom, pp. $21-43$.

Loon, P. van, (1994), De organisatie van het financieeleconomische management binnen een gemeente, in: Verheyen, P. (red.), Non-profit in bedriif, zeventien biidragen aan de non-profit economie, Kluwer, pp. 199 213.

Rivett, P. en P. Speak, (1991), The Financial Jung/e, a guide to financial instruments, 2nd edition, Coopers \& Lybrand

Starreveld, R., (1985), Bestuurlike informatieverzorging en de mede daarop gerichte administratieve organisatie, Samsom.

\section{NOTEN}

1 Aan de vormgeving van de te presenteren "denkmodellen" zijn vele discussies met collega's uit de adviespraktijk en uit de wetenschappelijke hoek voorafgegaan. Zonder de bijdragen van anderen tekort te willen doen, wil ik met name Prof. Dr. G.J. van Helden (RUG/VUA), Prof. Drs. C. Izeboud (VUA/Izeboud \& Sporrel), Drs. E.J. Schekkerman RA en Drs. A. Knibbe (beiden: Coopers \& Lybrand Management Consultants) bedanken voor hun kritische en inspirerende bijdragen in deze discussies.

2 Zie paragraaf 2 voor de inhoud van de functie en de reden van deze naamgeving.

3 Voor een meer gedetailleerde en op gemeentes afgestemde beschrijving zie: Van Loon \& Reinders Folmer, 1992.

4 In de discussie over de inhoud van het vak administratieve organisatie pleiten diverse auteurs voor een invulling zoals wij die voor werkvoorbereiding hebben gedefinieerd. Dit "oprekken" van het oorspronkelijk op de interne organisatie gerichte begrip blijkt verwarring te geven, zo is mijn ervaring Ik geef er de voorkeur aan een nieuw begrip te introduceren waarvan de "oude" AO onderdeel uitmaakt. Ook zijn er auteurs die hiertoe het begrip Bestuurlijke Informatiekunde introduceren. Dit betreft echter een veel breder gebied dan alleen de financiële en economische informatie waartoe ik mij in dit artikel wil beperken. 